\title{
EFEKTIVITAS PEMBERIAN PISANG AMBON DAN VITAMIN B UNTUK MENURUNKAN HIPEREMESIS GRAVIDARUM DI BPM ENDAH BEKTI
}

\section{THE EFFECTIVENEES OF MUSA ACUMINATA AND VITAMIN B TO REDUCE THE HIPEREMESIS GRAVIDARUM IN ENDAH BEKTI}

\author{
Elvika Fit Ari Shanti ${ }^{1}$, Liberty Barokah², Budi Rahayu ${ }^{3}$
}

\begin{abstract}
*1Program Studi Kebidanan (D3), Fakultas Kesehatan, Universitas Jenderal Achmad Yani Yogyakarta, Kampus 2 JI. Brawijaya Ring Road Barat, Ambarketawang, Gamping, Sleman, D.I.Yogyakarta 55294, Email: el_vicha@yahoo.co.id, Indonesia.

2 Program Studi Kebidanan (D3), Fakultas Kesehatan, Universitas Jenderal Achmad Yani Yogyakarta, Kampus 2 Jl. Brawijaya Ring Road Barat, Ambarketawang, Gamping, Sleman, D.I.Yogyakarta 55294, Indonesia.

${ }^{3}$ Program Studi Kebidanan (D3), Fakultas Kesehatan, Universitas Jenderal Achmad Yani Yogyakarta, Kampus 2 Jl. Brawijaya Ring Road Barat, Ambarketawang, Gamping, Sleman, D.I.Yogyakarta 55294, Indonesia.
\end{abstract}

\begin{abstract}
Background: Endocrine system changes during pregnancy are important to keep the pregnancy, fetal growth and post partum recovery. Around $50-90 \%$ of pregnant women experience vomit and nausea. To solve those problems, 'pisang ambon' (Musa paradisiacal) consumption is one of choices because of its flavonoid and vitamin B6 which can overcome vomit and nausea in pregnancy.

Objective: The aim of this research was to identify the effectiveness between pisang ambon (Musa paradisiacal) consumption and vitamin B6 to reduce hyperemesis gravidarum in BPM Endah Bekti.

Methods: A quasy experimental design with two-group posttest only was assigned to 20 pregnant women on their first trimester. First ten sample was given vitamin B6 and the other ten sample were given vitamin B6 plus pisang ambon. Data were then analyzed using two independent mean difference test.

Results: The result shows that in vitamin B6 consumption for hyperemesis gravidarum in $10 \%$ pregnant women were in the effective category. While in the pisang ambon consumption shows $100 \%$ of pregnant women are in the effective category.

Conclusion: There is difference in effectiveness between vitamin B6 and pisang ambon consumption to overcome hyperemesis gravidarum $(p=0,003<\alpha)$.
\end{abstract}

Keywords: Hiperemesis gravidarum, vitamin B6, Pisang ambon

\section{PENDAHULUAN}

Pada kehamilan terdapat perubahan

besar pada sistem endokrin yang penting terjadi untuk mempertahankan kehamilan, pertumbuhan normal janin, dan pemulihan pascapartum (nifas). Tes Human Chorionic Gonadotrophin (HCG) positif dan kadar HCG meningkat menjadi dua kali lipat sejak 48 jam sampai kehamilan berusia 6 minggu. ${ }^{1}$.

Sekitar $50-90 \%$ perempuan hamil mengalami keluhan mual muntah. Mual dan muntah biasanya dimulai pada kehamilan minggu ke 9 sampai pada minggu ke 10, memberat pada minggu ke 11 dan ke 13, dan berakhir pada minggu ke 12 sampai ke 14 . Hanya pada 1-10\% kehamilan berlanjut melewati minggu ke 20 sampai ke 22 minggu.

Terjadinya hiperemesis gravidarum dimana keluhan mual dan muntah hebat lebih dari 10 kali sehari dalam masa kehamilan dapat menyebabkan kekurangan cairan, penurunan berat badan, atau gangguan 
elektrolit, sehingga menganggu aktivitas sehari-hari dan membahayakan janin dalam kandungan. Mual dan muntah berlebihan ini dapat menyebabkan terjadinya ketidakseimbangan kadar elektrolit, penurunan berat badan (lebih dari $5 \%$ berat badan awal), dehidrasi, ketosis, dan kekurangan nutrisi.

Salah satu cara farmakologis yang dapat digunakan untuk mengatasi mual dan muntah pada kehamilan adalah dengan mengonsumsi piridoksin (vitamin B6). ${ }^{2}$ Suplementasi multivitamin secara bermakna mampu mengurangi kejadian mencegah insiden hiperemesis gravidarum. ${ }^{2}$ Vitamin B6 merupakan koenzim yang berperan dalam metabolisme lipid, karbohidrat dan asam amino. Vitamin B6 merupakan ko-enzim berbagai jalur metabolisme protein dimana peningkatan kebutuhan protein pada trimester I diikuti peningkatan asupan vitamin B6. Vitamin B6 diperlukan untuk sintesa serotonin dari tryptophan. Dosis vitamin B6 yang cukup efektif berkisar 12,5-25 mg per hari tiap 8 jam. Defisiensi vitamin B6 akan menyebabkan kadar serotonin rendah sehingga saraf panca indera akan semakin sensitif yang menyebabkan ibu mudah mual dan muntah.

Selain terapi yang bersifat farmakologis, keluhan hyperemesis gravidarum dapat diatasi dengan menggunakan pendekatan non farmakologis diantara adalah dengan mengonsumsi pisang ambon (Musa paradisiaca) yang banyak kandungan flavonoid serta vitamin B 6 yang mampu mngatasi mual muntah pada kehamilan. $^{3}$

\section{BAHAN DAN CARA PENELITIAN}

Penelitian ini menggunakan desain Quasi Experimental. Analisis data dilakukan dengan Uji beda dua mean independen. Rancangan penelitian digunakan dengan Two Group Only Post Tes Design. Dalam Rancangan ini sampel dibagi menjadi 2 kelompok yaitu: Kelompok 1 diberi Vitamin B6 dosis $3 \times 10$ gram sebanyak 10 ibu hamil. Kelompok 2 diberi pisang ambon dengan dosis 2x $100 \mathrm{mg}$ (1 pisang ambon segar mempunyai berat sekitar 100 gram) sebanyak 10 ibu hamil. Pemberian vitamin B6 dan pisang ambon dilakukan selama 3 minggu. Pemeriksaan frekuensi mual muntah pada minggu ke-1, ke-2 dan ke-3 setelah pemberian vitamin $\mathrm{B} 6$ dan pisang ambon. Ibu hamil diberikan lembar observasi untuk mencatat frekuensi mual muntah. Dikatakan efektif jika mual muntah $\leq 10 \times$ perhari.

\section{HASIL DAN PEMBAHASAN}

Tabel 1. Pemberian Vitamin B6

\begin{tabular}{|c|c|c|}
\hline $\begin{array}{c}\text { Hiperemesis } \\
\text { Gravidarum } \\
\text { Efektif }\end{array}$ & $\begin{array}{c}\begin{array}{c}\text { Frekuensi } \\
\text { (n) }\end{array} \\
10\end{array}$ & $\begin{array}{c}\text { Persentase } \\
\mathbf{( \% )} \\
100\end{array}$ \\
\hline Tidak Efektif & 0 & 0 \\
\hline
\end{tabular}

vitamin B6 efektif untuk menurunkan frekuensi mual muntah ditandai semua responden masuk kategori efektif sebanyak $10(100 \%)$. 
Tabel 2. Pemberian Pisang Ambon

\begin{tabular}{lll}
\hline $\begin{array}{l}\text { Hiperemesis } \\
\text { Gravidarum }\end{array}$ & $\begin{array}{l}\text { Frekuensi } \\
\text { (n) }\end{array}$ & $\begin{array}{l}\text { Persentase } \\
\mathbf{( \% )}\end{array}$ \\
Efektif & 10 & 100 \\
Tidak efektif & 0 & 0
\end{tabular}

Berdasarkan tabel 2, dapat diketahui bahwa pemberian pisang ambon efektif untuk menurunkan frekuensi mual muntah ditandai dengan semua responden masuk dalam kategori efektif sebanyak 10 (100\%).

Tabel 3. Perbedaan antara pemberian vitamin B dengan pisang ambon terhadap frekuensi mual muntah

\begin{tabular}{ccccccc}
\hline Kelompok & $\mathbf{F}$ & $\mathbf{( \% )}$ & Kategori & Min & Max & $\mathbf{P}$ \\
\hline $\begin{array}{c}\text { Pemberian } \\
\text { Vitamin } \\
\text { B6 }\end{array}$ & 10 & 100 & efektif & $\mathbf{0}$ & $\mathbf{8}$ & \\
& & & & & &
\end{tabular}

\begin{tabular}{lllllll}
\hline $\begin{array}{c}\text { Pemberian } \\
\text { Pisang }\end{array}$ & 10 & 100 & efektif & 0 & 6 & 0,003 \\
\cline { 1 - 2 } & & & & & &
\end{tabular}

Ambon dan

vitamin B6

Sumber : Data Primer, 2017

Berdasarkan tabel 3, dapat diketahui bahwa nilai $p(0,003<0,05)$ artinya terdapat perbedaan antara pemberian Vitamin B6 dengan pisang ambon terhadap frekuensi mual pada ibu hamil. Tabel di atas juga menunjukkan bahwa frekuensi mual pada kelompok pemberian vitamin B6 semua masuk dalam kategori efektif, begitu juga dengan kelompok pemberian pisang ambon dan vitamin B6 juga semua dalam kategori Efektif. Hasil dari analisis univariat, nilai minimal dan maksimal terlihat lebih efektif pemberian pisang ambon dan pemberian vitamin B6. Nilai maksimal lebih kecil dibandingkan dengan pemberian vitamin $\mathrm{B} 6$.

Berdasarkan hasil penelitian pada tabel 1 pemberian vitamin B6 efektif untuk menurunkan frekuensi mual muntah ditandai dengan semua responden masuk dalam kategori efektif sebanyak 10 (100\%). Penelitian ini menyimpulkan bahwa bukti yang mendukung hanya terbatas pada penggunaan terapi farmakologis termasuk vitamin B6 dan obat-obatan antiemetik. Vitamin B6 merupakan pilihan utama dalam mengurangi mual muntah dalam kehamilan. Ulasan sistematik Cochrane juga memperlihatkan vitamin B6 (pyridoxine) efektif mengurangi gejala mual muntah, walaupun tidak terdapat bukti pyridoxine mengurangi frekuensi muntah. Patofisiologi hiperemesis gravidarum dapat disebabkan karena peningkatan Hormone Chorionic Gonodhotropin (HCG) dapat menjadi faktor mual dan muntah. Hiperemesis gravidarum yang merupakan komplikasi ibu hamil muda bila terjadi terus menerus dapat mengakibatkan dehidrasi, ketidakseimbangan elektrolit, serta dapat mengakibatkan cadangan karbohidrat dan lemak habis terpakai untuk keperluan energy. ${ }^{4}$ Rasa mual dan muntah yang berlebih dapat dikendalikan dengan mengonsumsi vitamin B6 yang umumnya terdapat pada daging ayam, kentang, sawi, lobak dan kembang kol.

Berdasarkan tabel 2, dapat diketahui bahwa pemberian pisang ambon menurunkan frekuensi mual muntah ditandai dengan semua responden masuk dalam kategori efektif sebanyak 10 (100\%). Kandungan vitamin B6, vitamin C dan zat besi pada buah pisang ambon dapat 
membantu memproduksi antibodi, metabolisme lemak, sel-sel darah merah, serta menstimulasi produksi hemoglobin dalam darah pada penderita anemia. Pisang mengandung vitamin B6 adalah vitamin yang larut di dalam air. Vitamin B6 dapat membantu meningkatkan pengembangan sel sistem syaraf pusat pada janin. ${ }^{5}$

Hasil penelitian terdahulu menyatakan bahwa penyerapan zat besi total pada 100 gram pisang matang adalah 0,86 mg. ${ }^{6}$ Besi nonheme yang terdapat dalam pisang ambon ketika berada dalam lambung akan diabsorpsi oleh vitamin C (9 mg).

Berdasarkan tabel 3 frekuensi mual pada ibu hamil antara kelompok yang diberikan Vitamin B6 saja dengan kelompok yang diberikan pisang ambon ditambah vitamin B6 menunjukkan bahwa semua masuk dalam kategori efektif, Hal ini sejalan dengan penelitian yang mengatakan bahwa vitamin B6 merupakan koezim yang berperan dalam metabolisme lipid,karbohidrat dan asam amino. peranan vitamin B6 untuk mnegatasi hipermiesis. dosis pemberian vitamin B6 cukup efektif berkisar 12,5-25 mg perhari tiap 8 jam. ${ }^{7}$ Suplementasi multivitamin secara bermakna mengurangi kejadian mencegah insiden hiperemesis gravidarum. ${ }^{3}$ Hasil penelitian ini terjadi penurunan mual muntah pada ibu hamil trimester 1 yang diberikan vitamin B6, walaupun penurunan nilai rata rata tersebut sangat kecil namun tetap membawa perubahan pada kondisi ibu hamil jika mengonsumsi vitamin B6.
Buah pisang ambon mengandung vitamin B6, vitamin $\mathrm{C}$ dan zat besi yang dapat membantu penyerapan zat besi dengan cepat Karen mampu mengubah besi feri menjadi fero yang siap diserap oleh tubuh. ${ }^{8}$

\section{KESIMPULAN}

Pemberian Vitamin B6 secara tunggal maupun pemberian vitamin B6 ditambah dengan pisang ambon dapat berperan secara efektif dalam mengatasi hiperemesis gravidarum. Akan tetapi pemberian vitamin B6 ditambah dengan pisang ambon dapat lebih efektif dibandingkan pemberian vitamin B6 secara tunggal dalam mengatasi hyperemesis gravidarum.

\section{KEPUSTAKAAN}

1. Kusmiyati, Yuni, et all. Perawatan lbu Hamil asuhan lbu Hamil. Yogyakarta: Fitramaya. 2009

2. Petik D, Puho E, Czeizel AE. Evaluation of maternal infusion therapy duringpregnancy for fetal development. Int J Med Sci. Oct 2005;2(4):137-42.

3. Ehiowemwenguan, G., Emoghene, A. O.1 and Inetianbor, J.E.Antibacterial and phytochemical analysis of Banana fruit peel. IOSR Journal Of Pharmacy (e)ISSN: 2250-3013, (p)-ISSN: 2319-4219. Volume 4, Issue 8 (August 2014), PP. 1825

4. Wiknjosastro, Hanifa. "Ilmu Kebidanan, Edisi ketiga, Cetakan kesembilan." Jakarta: Yayasan Bina Pustaka Sarwono Prawirohardjo. 2007

5. Ratih, Rini Harini; Qomariah, Siti. Efektifitas Konsumsi Buah Pisang Terhadap Emesis Gravidarum Trimester I di Kabupaten Kampar 2017. . Prosiding CELSciTech, S.I.,v. 2 p. SCI-31 - SCI-34, oct. 2017. ISSN 2541-3023.

6. Garcia, F. A. et al. First report of Fusarium oxysporum f. sp. cubense 
tropical race 4 associated with Panama disease of banana outside Southeast Asia. Plant Dis. 98, 694 (2014)

7. Hallak, M. Hyperemesis gravidarum. Effects on fetal outcome. Obstet Gynecol. 1996.
8. Bakta, I.M. Hematogi Klinik Ringkas. Jakarta: Penerbit Buku Kedokteran EGC. 2015. 